\title{
Bartosz Szutkiewicz
}

Białystok

\section{Polska a Mołdawia w latach 1551-1572}

Celem niniejszej pracy jest przedstawienie stosunków polsko-mołdawskich w latach 1551-1572. Okres ten wpisujący się w panowanie Zygmunta Augusta charakteryzował się niezwykłą dynamiką w relacjach z Hospodarstwem Mołdawskim. Stanowił on również preludium do obserwowanej szczególnie pod koniec XVI oraz w pierwszych dwóch dekadach XVII wieku, wzmożonej w tym rejonie aktywności zarówno możnowładztwa zamieszkującego południowo-wschodnią część Rzeczpospolitej, jak i całego państwa polsko-litewskiego. Ówczesne zainteresowanie tym regionem miało charakter wielopłaszczyznowy, począwszy od związków kulturowych, historycznych, sięgających okresu średniowiecza, poprzez zwykłą ambicją i rozumianą nieraz w sposób dość specyficzny, rację stanu. Mając na uwadze zwierzchność Wysokiej Porty nad obydwoma księstwami naddunajskimi, wzajemne relacje $\mathrm{z}$ Mołdawią w wybranym okresie naturalnie wpisywały się w szerszy kontekst stosunków polsko-tureckich. Również nie bez znaczenia były interesy habsburskie, w realizowanie których nieraz zaangażowani byli koronni możnowładcy.

Omawiając źródła i literaturę, w pierwszej kolejności należy zwrócić na materiał rękopiśmienny, a w szczególności na Kronikę za Zygmunta Augusta w Knyszynie zmarłego roku $1572^{1}$ oraz źródła zawarte w Tekach Naruszewicza ${ }^{2}$. W związku zależnością Mołdawii względem Turcji, dużą wartość źródłową dla niniejszego tekstu miały korespondencja dyplomatyczna oraz wszelkie umowy zawierane i wymieniane pomiędzy stroną polską a Wysoką Portą ${ }^{3}$. Wiele wzmia-

1 Biblioteka im Raczyńskich w Poznaniu, nr 196 (dalej cyt. BRacz. nr 196).

2 Biblioteka Muzeum Narodowego im. Czartoryskich w Krakowie, Teki Naruszewicza, nr 80 (dalej cyt. BCzart. nr 80).

3 Katalog dokumentów tureckich do dziejów Polski i krajów ościennych w latach 1455-1672, oprac. Z. Abrahamowicz, Warszawa 1959 (dalej cyt. KDT); D. Kołodziejczyk, Ottoman - Polish Diplomatic Relations (15th-18th Century). An Annotated edition of ahdnames and other documents, Boston 2000; J. Pajewski, Legacja Piotra Zborowskiego do Turcji w 1568 roku. Materiały do historii stosunków polsko-tureckich za panowania Zygmunta Augusta, „Rocznik Orientalistyczny”, t. XII, Lwów 1936. 
nek źródłowych dotyczących interesującego mnie zagadnienia możemy znaleźć także na kartach dzieł Marcina Bielskiego ${ }^{4}$, Stanisława Lasickiego $^{5}$ oraz Bartosza Paprockiego ${ }^{6}$. Sprawom mołdawskim został również poświęcony $\mathrm{X}$ tom Źródeł Dziejowych obejmujący między innymi listy hospodarów mołdawskich do władców polskich ${ }^{7}$. Zainteresowanie króla obsadą tronu hospodarskiego oraz jego stosunek do poszczególnych interwencji w Mołdawii obrazują Akta podkanclerskie Franciszka Krasińskiego ${ }^{8}$ oraz Dzieje w Koronie Polskiej Lukasza Górnickiego'.

$\mathrm{Z}$ prac poświęconych bezpośrednio oraz pośrednio interesującemu nas zagadnieniu najbardziej kompleksowe omówienie stosunków polsko-mołdawskich znajdziemy na kartach pracy Zdzisława Spieralskiego ${ }^{10}$. Mając na uwadze kontekst pozycji Wysokiej Porty, warto sięgnąć po prace traktujące o stosunkach polsko-tureckich z niezwykle interesującą pracą Andrzeja Dziubińskiego na czele ${ }^{11}$. Zarys problemu mołdawskiego w kontekście wzajemnych relacji z Turcją przedstawiła również Ilona Czamańska ${ }^{12}$. Inna praca tej samej autorki poświęcona rodowi Wiśniowieckich objaśnia podstawę udziału oraz samo zaangażowanie Dymitra Wiśniowieckiego w walkach o tron hospodarski ${ }^{13}$. Informacje na temat zagadnienia międzynarodowego kontekstu stosunków polsko-mołdawskich oraz relacji dwustronnych możemy znaleźć również w tomie pierwszym Historii dyplomacji polskiej ${ }^{14}$.

Po śmierci Piotra Rareşa w 1546 roku hospodarem mołdawskim został jego syn Eliasz. Jego protureckie rządy szybko doprowadziły do powstania licznego grona oponentów. Część bojarów znajdujących się w opozycji do władcy szukała oparcia w Polsce, gdzie Zygmunt August nieopatrznie odesłał ich do wojewody ruskiego i hetmana polnego Mikołaja Sieniawskiego. Sytuacji nie poprawiła zmiana na tronie hospodarskim. W 1551 roku zbiegłego do Turcji Eliasza

\footnotetext{
4 M. Bielski, Kronika polska, wyd. K. J. Turowski, t. II, Sanok 1856.

5 S. Łasicki, Historia wtargnienia Polaków na Wołoszczyznę, oprac. W. Syrokomla, Petersburg - Mohylew 1855.

6 B. Paprocki, Herby rycerstwa polskiego, wyg K. J. Turowski, Kraków 1858.

7 Źródła dziejowe, wyd. A. Jabłonowski, t. X, Warszawa 1878.

8 Akta podkanclerskie Franciszka Krasińskiego, oprac. W. Chomętowski, t. III, Warszawa 1871.

9 Ł. Górnicki, Dzieje w Koronie Polskiej, oprac. H. Barycz, Wrocław 2003.

10 Z. Spieralski, Awantury mołdawskie, Warszawa 1967.

11 A. Dziubiński, Stosunki dyplomatyczne polsko-tureckie w latach 1500-1572 w kontekście międzynarodowym, Wrocław 2005.

12 I. Czamańska, Mołdawia i Wołoszczyzna w stosunkach polsko-tureckich w XV-XVII wieku, „Balcanica - Posnaniensia”, t. IV, Poznań 1989.

13 I. Czamańska, Wiśniowieccy. Monografia rodu, Poznań 2007.

14 Historia dyplomacji polskiej, t I: Połowa X w. - 1572, pod red. M. Biskupa, Warszawa 1982.
} 
zastąpił jego brat jako Stefan VII, który okazał się okrutnikiem ${ }^{15}$. Nowy hospodar pomimo swojej lojalności wobec Turcji nie był pewny swojej pozycji. W związku z tym sam zdecydował się szukać pomocy między innymi u króla Zygmunta Augusta. Pod koniec 1551 roku do Wilna, gdzie przebywał wówczas monarcha, przybyli posłowie Stefana. Hospodar mołdawski zapewniał o swojej przyjaźni, tłumaczył występki swego brata, dążył między innymi do obustronnego rozwiązania sporów granicznych, oraz zawarł wieczyste przymierze, które król w obecności dostojników litewskich zaprzysiąg ${ }^{16}$. Obok Stefana VII o przychylność Korony zabiegał również pretendent do tronu mołdawskiego, Iwonia syn Stefana V. Najprawdopodobniej podczas sejmu piotrkowskiego na początku 1552 roku zawiązała się idea kolejnej interwencji polskiej w Mołdawii, autorstwa Jana Tarnowskiego. W szerszej perspektywie miała ona doprowadzić do pogorszenia stosunków polsko-tureckich, a nawet do konfrontacji. Pierwotnie w zamyśle Tarnowskiego nowym hospodarem mołdawskim miał zostać Iwonia, którego przedstawiono posłom habsburskim jako odpowiedniego kandydata. Uzyskał on już w 1551 roku wsparcie kilku chorągwi hetmana polnego Sieniawskiego, jednak jego oddziały zostały pokonane tuż przy granicy polsko-mołdawskiej. Strona polska oficjalnie odcięła się od tej akcji, tłumacząc posłom Stefana, iż była to prywatna inicjatywa, a dodatkowo król wówczas jeszcze nie wiedział o wstąpieniu na tron nowego hospodara ${ }^{17}$. Wiosną 1552 roku u hetmana polnego Mikołaja Sieniawskiego w Jarmolińcach zgromadzili się bojarzy mołdawscy. Ostatecznie zdecydowano się, aby zamiast Iwonii na tronie hospodarskim osadzić Piotra Lapuşneau, nieślubnego syna Bogdana III. Na korzyść nowego pretendenta oprócz starszeństwa przemawiało przede wszystkim pozyskanie wsparcia wodza wojsk habsburskich w Siedmiogrodzie, margrabiego Castaldo. Stefan VII Rareş został zamordowany 1 IX 1552 roku. Nowym hospodarem został Jan Joldea. Rządy świeżo upieczonego hospodara trwały zaledwie 3 dni, a ich kres nastał za sprawą oddziałów polskich osłaniających Piotra Lapuşneau, które pojmały Jana Joldeę. Hetman Sieniawski na wieść o zamordowaniu Stefana VII natychmiast wyprawił z obozu nad Dniestrem pretendenta wraz z oddziałami pod wodzą

15 Eliasz przeszedł na mahometanizm i został sandżakbegiem Sylistrii, M. Bielski, op. cit., t. II, s. 1107; Źródła dziejowe..., t. X, s. CXXXV.

16 Poselstwo Jana Strurzy i Piotra Krky nie czekając na glejt wydany wcześniej gońcowi mołdawskiemu Awramowi Baniłowskiemu, zjawiło się u Zygmunta Augusta przebywającego wówczas w Wilnie w I połowie XII 1551 roku. Posłowie otrzymali 2 I 1552 roku odpis oraz glejt na dalszy przejazd do Moskwy; Źródła dziejowe..., t. X, s. CXXXIII-CXXXV, 140-149, Odpowiedź Zygmunta Augusta posłom wojewody Stefana VII przez pisarza Hornostaja udzielona, Wilno, 15 XII $1551 \mathrm{r}$.

17 Źródła dziejowe..., t. X, s. CXXXIII, Odpowiedź posłom mołdawskim dana przez pisarza królewskiego dnia 15 XII 1551 r.; Scriptores Rerum Polonicarum, t. I, Kraków 1872, s. 51-53 (dalej cyt. SRP), List Z. Herberstein, J. Lang do Ferdynanda I, Piotrków, 14-21 II 1552; W. Dworzaczek, Hetman Jan Tarnowski, Warszawa 1985, s. 179-180. 
starosty kamienieckiego, Macieja Włodka. Przed przekroczeniem Dniestru Piotr, już jako Aleksander IV Lapuşneau, złożył 5 IX w Bakocie na ręce Sieniawskiego w obecności 23 rotmistrzów polskich hołd lenny. Pod aktem homagialnym podpisało się również 66 bojarów mołdawskich ${ }^{18}$.

Akcja wprowadzenia na tron Aleksandra IV Lapuşneau, zakończona błyskawicznym powodzeniem, na pierwszy rzut oka wydawać by się mogła niemałym sukcesem strony polskiej. Wszystko działo się jednak bez wiedzy Zygmunta Augusta, który starał się utrzymywać dobre stosunki z Turcją. Król otrzymał wiadomość o akcji Sieniawskiego w niecałe dwa tygodnie po odebraniu przez hetmana polnego z rąk Lapuşneau hołdu lennego. Natychmiast wysłane zostały uniwersały nakazujące kategorycznie odwrót z Mołdawii ${ }^{19}$. Sam hołd został przez króla odrzucony ze względu na stosunki z Wysoką Portą. Dla Zygmunta Augusta dodatkową komplikację stanowił również udział Habsburgów w całym przedsięwzięciu. Paradoksalnie, interwencja Sieniawskiego poniekąd pomogła królowi w osiągnięciu porozumienia z Wysoką Portą. Odrzucenie hołdu wraz z innymi przyjaznymi gestami złożyły się na odnowienie przez poselstwo kasztelana lwowskiego Stanisława Tęczyńskiego 1 VIII 1553 roku traktatu pokojowego pomiędzy Koroną a Turcją. W owym układzie znalazł się również passus traktujący o zakazie napadów mołdawskich na ziemie polskie ${ }^{20}$. Aleksander Lapuşneau wprowadzony na tron mołdawski przy udziale zarówno Polaków, jak i Habsburgów z konieczności musiał zwrócić się w kierunku Turcji. Ostatecznie nowy hospodar przy wsparciu dyplomacji koronnej został zatwierdzony przez Wysoką Portę oraz złożył 1 VI 1553 roku przysięgę na wierność Koronie Polskiej. $\mathrm{W}$ porównaniu do hołdu z Bakoty została ona uzupełniona o zobowiązania wojskowe. Wkrótce wraz z postępującym konfliktem turecko-habsburskim, stał się on również wiernym sojusznikiem Zapolyów, co w ostatecznym rozrachunku było na rękę Zygmuntowi Augustowi, związanemu z nimi poprzez małżeństwo siostry ${ }^{21}$.

Warto w tym miejscu nadmienić, iż udział Sieniawskiego i jazdy obrony potocznej nie był jedynym rodzimym akcentem w walce o tron hospodarski. Latem 1553 roku na tereny tureckiego Budziaku ruszył spokrewniony z dynastią Rareşów, Dymitr Wiśniowiecki²2. Król wysłał za nim Konstantego Ostrogskiego,

\footnotetext{
18 A. Dziubiński, Stosunki dyplomatyczne..., s. 203; Z. Spieralski, Jan Tarnowski, Warszawa 1977, s. 369-370.

19 Ł. Górnicki, op. cit., t. II, s. 61; SRP, s. 96. In Tapia, pago citerioris Prussiae 20 IX 1552.

20 D. Kołodziejczyk, op. cit., s. 234-237, 239-242.

21 Już w 1554 roku Aleksander wespół z Sulejmanem namawiał Izabelę wraz z synem do wyjazdu do Siedmiogrodu, M. Bielski, op. cit., t. II, s. 1119.

22 Istnieje szereg wzmianek źródłowych mówiących o pokrewieństwie Dymitra Wiśniowieckiego z dynastią Rareş por. I. Czamańska, Wiśniowieccy..., s. 42, 67, 69.
} 
jednak ten Dymitra dogonić nie zdołał. Wiśniowiecki zamierzał wystąpić w obronie Konstantyna, najmłodszego syna Piotra Rareşa. W tym celu jego siły połączyły się z oddziałami byłego hospodara mołdawskiego Eliasza, wówczas sandżakbega Sylistrii. Ostatecznie kres tej wyprawie położył Sulejman, dążący do uspokojenia sytuacji w regionie. Młody Konstantyn został zgładzony w Stambule. Podobny los najprawdopodobniej spotkał Eliasza, który został odwołany z urzędu sandżakbega i odprowadzony pod zbrojną eskortą do Aleppo, gdzie wszelki słuch po nim zaginął23. Pomimo protureckiego nastawienia rządy Aleksandra Lapuşneau charakteryzowały się pewną stabilizacją na gruncie wewnętrznym.

Postępująca chwiejność władzy hospodarskiej w Mołdawii miała się okazać po raz kolejny regułą, którą postanowili wykorzystać dwaj awanturnicy o niezmierzonej ambicji: Olbracht Łaski oraz Jan Jakub Heraklides Basilikos. Pierwszy z nich, poddany zarówno Zygmunta Augusta, jak i cesarza Ferdynanda I, zaliczał się do grona największych awanturników w skali całej XVI-wiecznej Europy. Drugi natomiast, nota bene syn greckiego marynarza, był niesłychanie inteligentnym oszustem, który przewinął się między innymi przez dwory hiszpański i pruski oraz posługiwał się biegle kilkoma językami. Basilikos trafił do Polski za pośrednictwem Albrechta Hohenzollerna. Tam też w jego umyśle zrodziła się zgoła na pierwszy rzut oka fantastyczna koncepcja opanowania tronu mołdawskiego ${ }^{24}$. W 1558 roku Basilikos wyjednał u kanclerza wielkiego litewskiego Mikołaja Radziwiłła „Czarnego” list polecający, z którym udał się na dwór mołdawski. Na miejscu podał się za krewnego żony Aleksandra oraz niezwłocznie przystąpił do montowania własnego zaplecza politycznego. Hospodar dość szybko zorientował się $\mathrm{w}$ planach oszusta, ten jednak zdołał zawczasu uciec do Siedmiogrodu, gdzie poznał Olbrachta Łaskiego. Panowie szybko znaleźli wspólny język i już w 1559 roku rozpoczęły się przygotowania do wyprawy ${ }^{25}$. Wieści o niej szybko rozeszły się wśród najemników i awanturników wszelkiej maści, w związku z czym nie umknęły uwadze zarówno Zygmunta Augusta jak i Aleksandra Lapuşneau. Jakby tego było mało Laski pokusił się o układy z cesarzem, których elementem było następstwo tronu po bezdzietnej śmierci króla. Dodatkowo prowadzona była kampania w kręgach kalwińskiej szlachty. Reakcja króla mogła być tylko jedna. Polecił on Sieniawskiemu zatrzymanie armii Basilikosa i Łaskiego. Hetman dopadł awanturników pod Pomorzanami i po krótkiej walce rozbił ich siły oraz skonfiskował część taboru wraz z całą artylerią ${ }^{26}$.

\footnotetext{
23 I. Czamańska, Wiśniowieccy..., s. 72.

24 M. Bielski, op. cit., t. II, s. 1138.

2529 XI 1559 r. zawarta została umowa, w ramach której w zamian za sfinansowanie wyprawy Łaski otrzyma później zwrot kosztów oraz wysokie stanowiska państwowe, w tym urząd hetmana; Z. Spieralski, Awantury..., s. 122.
}

26 M. Bielski, op. cit., t. II, s. 1138-1139; Z. Spieralski, Awantury..., s. 122-123. 
Ponadto w początkach 1561 roku do Aleksandra wysłane zostało poselstwo zapewniające o przyjaźni i pokoju ze strony króla. W obecności posłów hospodar mołdawski zaprzysiągł po raz kolejny dawne układy ${ }^{27}$.

Nie zważając na porażkę, Basilikos wraz z Łaskim podjęli kolejną próbę. Tym razem pozyskali dla swoich planów cesarza Ferdynanda I oraz zadbali o poparcie Albrechta Hohenzollerna. Latem 1561 roku Sieniawskiego odwiedził jadący do Mołdawii poseł księcia pruskiego Marceli Konarski, będący siostrzeńcem hetmana ${ }^{28}$. Lepiej przygotowany był plan całej akcji, zakładający przemarsz inną trasą, przebiegającą głównie poza terytoriami koronnymi. Zastosowano również dezinformację w postaci rozpuszczenia plotki o śmierci Basilikosa. Wyprawiony został również demonstracyjny pogrzeb. Późną wiosną 1561 roku zostały wydane uniwersały królewskie zabraniające udziału w wyprawach na Mołdawię w związku z czym podejmująca działania w początkach listopada nowa armia duetu awanturników była złożona tym razem głównie z obcokrajowców. Zaskoczenie było zupełne. 16 XI Lapusneau został pokonany, a ścigające go później oddziały Łaskiego dotarły niemal do Dunaju. Była to jednak połowa sukcesu. Basilikos doskonale rozumiał konieczność uznania jego rządów przez Turcję. Aby to osiągnąć, zdecydował się sięgnąć, mówiąc oględnie, po „brzęczące argumenty”. Przekupił część członków dywanu oraz zgodził się płacić haracz w wysokości 20000 dukatów. Korzystną okolicznością było zaangażowanie Wysokiej Porty w konflikt z Persją. Ostatecznie Sulejman uznał syna marynarza i ten mógł spokojnie sprawować władzę w Mołdawii jako Jan II. Łaskiemu na poczet długów, których nowy hospodar wobec wydatków poniesionych względem Turcji, nie był w stanie uregulować, przekazano zamek chocimski. Na całej sprawie nie ucierpiały również stosunki polsko-tureckie. Sulejman uznał, iż Zygmunt August zrobił aż nadto, by powstrzymać misję awanturników ${ }^{29}$.

Basilikos dość szybko padł ofiarą swoich zgoła fantastycznych planów zajęcia Siedmiogrodu i Hospodarstwa Wołoskiego oraz uderzenia na Turcję. Jego zamiary rozmijały się również kompletnie z interesami Zygmunta Augusta, który radził Sulejmanowi przywrócenie tronu Aleksandrowi ${ }^{30}$. Na gruncie wewnętrznym szybko dały znać o sobie skutki wysokiego opodatkowania ludności. Nie-

\footnotetext{
27 Źródła dziejowe..., t. X, s. CXLI.

28 M. Plewczyński, Mikołaj Sieniawski herbu Leliwa (1489-1569) [w:] Polski Stownik Biograficzny, t. XXXVII/1, Warszawa - Kraków, s. 125; Spieralski wskazuje z kolei na udział dyplomacji habsburskiej; Z. Spieralski, Awantury..., s. 124.

${ }^{29} K D T$, nr 168, s. 165, List Sulejmana I do Zygmunta Augusta, Stambuł, 7-16 III 1562, nr 178, s. 173-174, List Ibrahima Beg'a do Zygmunta Augusta, Kraków, bd.; A. Dziubiński, Stosunki dyplomatyczne..., s. 228-229; Historia dyplomacji..., t. I, s. 692.

30 Por I. Czamańska, Jakub Basilikos Heraklidesa - droga do wyzwolenia Grecji?, „Balcanica Posnaniensia", IX/X, Poznań 1999, s. 133-152.
} 
zadowolenie budzili obcokrajowcy ściągani masowo przez Basilikosa. Dodatkowym czynnikiem była kalwińska konwersja hospodara oraz plany wprowadzenia kalwinizmu w państwie jako religii panującej. Zagrożeniem dla Basilikosa stał się również jego wspólnik, Olbracht Łaski, któremu Jan II odebrał Chocim, co też zmusiło awanturnika do pojednania się z królem na sejmie w Piotrkowie w 1563 roku. Przeprosiny za samowolne działania w Mołdawii nie oznaczały bynajmniej zarzucenia planów o jej podboju. Na sejmie w Piotrkowie Łaski zawarł porozumienie z innym osobnikiem swojego pokroju, Dymitrem Wiśniowieckim, również interesującym się tronem mołdawskim. Obaj jeszcze w lutym 1563 roku wyprawili się do Mołdawii, po czym sam Dymitr zaczął nękać ziemie Basilikosa zapewne z częstotliwością typową dla swoich wcześniejszych działań przeciwko Turkom i Tatarom ${ }^{31}$.

Basilikos widząc w Łaskim zagrożenie, starał się zapewnić sobie wsparcie innych możnowładców zarówno koronnych, jak i litewskich, ponadto dążył do ułagodzenia swego byłego wspólnika, wydając akt gwarantujący następstwo tronu $^{32}$. Kres rządów oszusta nastąpił jednak nie za sprawą duetu: Łaski-Wiśniowiecki. W lipcu 1563 roku przeciwko Basilikosowi wystąpili bojarzy ze Stefanem Tomżą na czele, wsparci przez wojska Zapolyi. Udział Siedmiogrodzian w przewrocie niewątpliwie wskazuje na to, iż zgodę na całą akcję wydał sułtan albo przynajmniej jego bliskie otoczenie. Basilikos został oblężony z niewielkim gronem zwolenników w Suczawie, gdzie zmuszony do poddania się, został zamordowany przez wyniesionego na tron hospodarski przywódcę buntu i jego stronników ${ }^{33}$. Los nie oszczędził również oprawców Basilikosa. Wobec braku poparcia ze strony Turcji, Stefan Tomża został zmuszony do ucieczki do Polski. Na nic zdało się wydanie Turkom Dymitra Wiśniowieckiego oraz okaleczenie części jego podkomendnych. Dymitr nie czekając na pomoc Łaskiego, zdecydował się odpowiedzieć na wezwanie do objęcia władzy wystosowane przez grupę bojarów mołdawskich, niemniej jednak po drodze jego oddziały zostały pobite przez Tomżę, a on sam dostał się do niewoli. Nowy hospodar tym podstępnym czynem ściągnął na siebie gniew szlachty polsko-litewskiej. Nic dziwnego, iż król w ramach rewanżu nie wydał Tomży sułtanowi, tylko kazał go ściąć na rynku lwowskim w obecności posła tureckiego Ibrahima beg'a ${ }^{34}$. Na tron mołdawski przy wsparciu tureckim powrócił Aleksander Lapusneau, ceniony również przez Zygmunta Augusta. Ów hospodar podczas drugiego panowania wykonywał liczne przyjazne gesty względem Korony Polskiej, niemniej jednak dał się

31 M. Bielski, op. cit., t. II, s. 1145; I. Czamańska, Wiśniowieccy.., 79-80.

32 I. Czamańska, Wiśniowieccy..., s. 79.

33 M. Bielski, op. cit., t. II, s. 1148; Z. Spieralski, Awantury..., s. 127.

34 M. Bielski, op. cit., t. II, s. 1148-1149; Udział w wydaniu Turkom Dymitra Wiśniowieckiego miał też powracający na tron Aleksander, I. Czamańska, Wiśniowieccy..., s. 80-81. 
również polskiemu władcy we znaki, przetrzymując posła oraz zezwalając na okazjonalne napady tatarsko-mołdawskie ${ }^{35}$.

Mając na uwadze uznanie przez Turcję Aleksandra Lapusneau oraz Basilikosa, wprowadzonych na tron przez samowolne interwencje prowadzone w dużej mierze przez Polaków, Zygmunt August zdecydował się podjąć próbę wytargowania w Stambule zgody na wyznaczanie hospodarów mołdawskich przez stronę polsko-litewską, co oznaczałoby utworzenie z hospodarstwa polsko-tureckim kondominium. Królowi chodziło o utrzymanie dobrych kontaktów z hospodarami wspierającymi na ogół królewskie interesy w Siedmiogrodzie oraz o powstrzymanie napadów wołoskich na Pokucie i inne ziemie południowe, które nasiliły się w latach 60-tych XVI wieku, pomimo bardzo poprawnych stosunków na linii: Suczawa-Kraków ${ }^{36}$. W początkach marca 1568 roku z misją do Stambułu wysłany został kasztelan wojnicki Piotr Zborowski. Nieszczęśliwym zbiegiem okoliczności w trakcie drogi 5 V 1568 roku otruty został Aleksander Lapuşneau. Znając pobieżnie cel misji posła polskiego, sułtan za namową wielkiego wezyra Mehmeda Sokołłu wysłał firman Bogdanowi, który był synem zmarłego hospodara. Zborowski próbował interweniować, niemniej jednak postawa wielkiego wezyra mającego ogromny wpływ na sułtana, była nieugięta. Podobnie rzecz miała się z samymi negocjacjami. Posła w niekorzystnej sytuacji postawił dodatkowo Łaski, najeżdżając na Oczaków, co znacznie pogorszyło i tak nieciekawe dla niego położenie. Cały ów splot niekorzystnych wypadków przełożył się na porażkę Zborowskiego w wielu punktach jego instrukcji, w tym także i tych dotyczących Mołdawii ${ }^{37}$.

Jak już wspomniałem wyżej, próby wzmocnienia władzy hospodarskiej oraz walka z bojarami doprowadziły do kolejnej, tym razem skutecznej, próby zamachu stanu. Wobec zabiegów strony polsko-litewskiej o przyznanie prawa wyboru hospodara, Turcy dość szybko uznali za nowego władcę syna Aleksandra Bogdana. Stanowcze poparcie Wysokiej Porty tymczasowo uspokoiło sytuację wewnętrzną. Nowy hospodar kontynuował politykę swego ojca starając się znaleźć oparcie i stronników w Koronie. W 1569 roku złożył hołd Zygmuntowi Augustowi, w ramach którego zobowiązał się do udzielenia w razie potrzeby wsparcia wojskowego ${ }^{38}$. Ponadto, zarówno poprzez małżeństwa sióstr, jak

35 KDT, nr 190, s. 186-187, List Selima II do Zygmunta Augusta, Stambuł, 5 III 1567; J. Pajewski, Legacja Piotra Zborowskiego..., Z. Spieralski, Awantury..., s. 129-130.

36 M. Bielski, op. cit., t. II, s. 1163; J. Pajewski, Legacja Piotra Zborowskiego..., s. 3.

37 Szerzej o misji Piotra Zborowskiego: A. Dziubiński, Stosunki dyplomatyczne..., s. 247-255; Historia dyplomacji..., s. 698-701; J. Pajewski, Legacja..., s. 1-52.

38 Hołd złożyło najprawdopodobniej poselstwo mołdawskie przebywające w Lublinie podczas obrad sejmu w dniach 6-16 II 1569 roku, Archiwum Główne Akt Dawnych, Archiwum Skarbu Koronnego, Rachunki poselskie, ks. 11, k. 2-5; M. Bielski, op. cit., t. II, ..., s. 1210. 
i własne, z córką kasztelana radomskiego Jana Tarły, starał się skoligacić z rodami polskimi ${ }^{39}$. Król cenił dobre stosunki z Bogdanem. W związku z tym bronił również spraw hospodara na forum międzynarodowym ${ }^{40}$.

Właśnie w celach matrymonialnych Bogdan IV udał się do Korony w początkach 1572 roku. Z miejsca spotkały go jednak nieprzyjemności ze strony niedoszłego teścia. Krzysztof Zborowski przypadkiem dowiedziawszy się o obecności hospodara mołdawskiego postanowił powetować sobie zawód, jakiego doznał w Suczawie związany z brakiem porozumienia w kwestii zawarcia małżeństwa z siostrą Bogdana IV. Jego słudzy uprowadzili Bogdana, raniąc go przy tym dwukrotnie. Hospodarowi udało się w końcu wykupić za sumę 6000 czerwonych złotych oraz za wstawiennictwem swego zięcia Paniewskiego ${ }^{41}$. Nieobecność Bogdana w kraju starał się wykorzystać Olbracht Łaski, wciąż marzący o tronie hospodarskim. Wojewoda sieradzki zaczął na przełomie 1571 i 1572 roku gromadzić na granicy znaczne oddziały wojska ${ }^{42}$. Zanim Łaski rozpoczął otwarte działania w Suczawie, opozycja, wykorzystując nieobecność Bogdana, dokonała przewrotu, ogłaszając hospodarem Iwonię. Jak już wspomniałem wyżej, nieślubny syn Stefana V, był już raz pretendentem do tronu mołdawskiego, niemniej jednak ostatecznie zastąpił go Aleksander Lapusneau. Wydawać by się mogło, że na korzyść Iwonii będą przemawiać dawne związki z Polską, jednak król zdecydował się poprzeć Bogdana ${ }^{43}$.

Pomimo fiaska misji Zborowskiego, w kwestii wyboru władcy Mołdawii przez stronę polsko-litewską, dotychczasowe doświadczenia związane ze zmianą hospodarów, nad którymi wobec odpowiednich kroków dyplomatycznych przechodziła do porządku dziennego Wysoka Porta, zachęciły króla do udzielenia zgody, a być może nawet do zainicjowania, następnej polskiej interwencji na terenie południowego sąsiada. Król zignorował przy tym ostrzeżenie tureckie przez ingerencją w sprawy mołdawskie oraz żądanie wydania Bogdana Wyso-

\footnotetext{
39 Jedna z sióstr Bogdana IV wyszła za mąż za starostę żydaczowskiego Kacpra Paniewskiego, druga natomiast była zaręczona Krzysztofem Zborowskim, małżeństwa jednak nic nie wyszło, co było następstwem kłótni o posag; BRacz. nr 196, s. 91; M. Bielski, op. cit., t. II, s. 1210; Ł. Górnicki, op. cit., s. 169; Z. Spieralski, Awantury..., s. 130.

40 Między innymi polska dyplomacja starała się udaremnić starania dysydentów mołdawskich na dworze cesarskim, Akta podkanclerskie..., t. III, s. 231-232; List Zygmunta Augusta do Lukasza Podoskiego, Warszawa, 7 XI 1571.

41 M. Bielski, op. cit., t. II, s. 1210-1211.

42 BCzart., nr 80, s. 7-9, Kopia listu Selima II do Zygmunta Augusta, Adrianopol, 13 II 1572 r.; Skrót listu [w:] KDT, nr 214, s. 207 z inną datą 8-16 I 1572 r.

43 Być może Iwonia stracił wiarygodność, przechodząc na służbę Iwana IV Groźnego, M. Bielski, op. cit., t. II, s. 1211; niemniej jednak, moim zdaniem, o poparciu Bogdana zdecydowały przede wszystkim dobre układy z jego ojcem Aleksandrem, oraz fakt, iż sam Bogdan zdecydował się na zbliżenie z Rzeczpospolitą.
} 
kiej Porcie ${ }^{44}$. Ponadto istniały przesłanki alarmujące o możliwym zaangażowaniu Tatarów w Mołdawii. Między innymi jeszcze w 1571 roku hetman Jazłowiecki przesłuchał jeńca, który zeznał, że wojsko tatarskie niebawem wkroczy do ziemi wołoskiej ${ }^{45}$. Ponadto niewyciągnięte zostały odpowiednie wnioski z porażki poselstwa Zborowskiego. Sam poseł zauważył, iż teraz będzie trzeba bardziej zabiegać o dobre stosunki i uważać, aby ich nie nadwyrężyć. Refleksja ta nasunęła się zapewne jej autorowi w perspektywie zmiany sułtana oraz postawy wielkiego wezyra Mehmeda Sokołłu, który jeszcze za panowania przychylnego Polsce Sulejmana zastąpił na tym stanowisku zmarłego w 1565 roku Semiz Alego ${ }^{46}$.

Pierwszym krokiem było wysłanie z listem do Selima Andrzeja Taranowskiego. Ponadto nie wiedząc o poparciu Wysokiej Porty dla Iwonii, Zygmunt August zgodził się nieoficjalnie na interwencję, która miała zachować pozory prywatnej wyprawy polskich możnowładców związanych z Bogdanem. Wodzem wyprawy został wojewoda podolski Mikołaj Mielecki ${ }^{47}$. Jeszcze w trakcie przygotowań lub na samym początku interwencji Wysoka Porta wysłała do króla kolejnego czausza tym razem domagając się wydania Bogdana posłańcowi wraz z rocznym haraczem jaki były hospodar miał zapłacić Turcji. Wiozący listy czausz Mustafa dotarł do Warszawy na początku maja, kiedy oddziały Mieleckiego wycofywały się już z Mołdawii ${ }^{48}$.

Wróćmy jednak do samej interwencji. Oddziały polskie przekroczyły w marcu Dniestr i dotarły aż pod Jassy, gdzie napotkały przeważające siły turecko-tatarskie wezwane na pomoc przez Iwonię. Wobec przewagi oraz składu wojsk przeciwnika, Mielecki zarządził odwrót. Król widząc powagę sytuacji, najprawdopodobniej rozkazał hetmanowi Jazłowieckiemu udać się nad Dniestr. Wojewodę ruskiego wezwał również na pomoc wycofujący się pod naporem przeciwnika Mielecki ${ }^{49}$. W nocy z 12 na 13 IV oddziały wojewody podolskiego dotarły do

$44 K D T$, nr 214, s. 207, List Selima II do Zygmunta Augusta, Adrianopol, 8-16 I 1572 r.; nr 215, s. 208, List Mehmeda Sokołu do Zygmunta Augusta, Adrianopol, 8-16 I 1572 r.

45 Jeńcem był znaczny Tatar pojmany przez Kozaków. Jego zeznania pokrywały się częściowo z zeznaniami innych Tatarów również schwytanych przez Kozaków, niemniej jednak pozostali mówili o możliwości napadu tatarsko-wołoskiego na ziemie koronne w związku z czym podniesiono alarm w województwach bracławskim, kijowskiego, ruskim, podolskim, lubelskim, bełzkim oraz wołyńskim, Akta podkanclerskie ..., t. III, s. 455-456.

46 J. Pajewski, Legacja..., s. 51.

47 Pomoc królewska nie ograniczała się do samego cichego pozwolenia na interwencję. Zapewne za wstawiennictwem samego Zygmunta Augusta Bogdanowi udzielili pożyczki Soderini - etatowi bankierzy króla, Akta podkanclerskie..., t. III, s. 333, List Franciszka Krasińskiego do Soderinich, Warszawa, 6 III 1571; M. Bielski, op. cit., t. II, s. 1210; Ł. Górnicki, op. cit., s. 169.

48 KDT, nr 216, s. 209, List Selima II do Zygmunta Augusta, Stambuł, 16-25 III 1572 r.; nr 217, s. 209, List Mehmeda Sokołłu do Zygmunta Augusta, Konstantynopol, 16-25 III 1572 r.

49 M. Bielski, op. cit., t. II, s. 1217-1218; S. Lasicki, Historia wtargnienia Polaków na Wołoszczyznę, oprac. W. Syrokomla, Petersburg - Mohylew 1855, s. 16-22. 
leżącego nad Dniestrem Chocimia, gdzie zajęły umocnione pozycje. Próba forsowania Dniestru w obecności tak licznych wojsk nieprzyjaciela mogła się skończyć katastrofą, w związku z czym Mielecki zdecydował się czekać na przybycie Jazłowieckiego. Hetman zjawił się dość szybko i z miejsca rozpoczął mediacje z sandżakbeg białogrodzkim dowodzącym oddziałami turecko-tatarskimi wspierającymi Iwonię. Jazłowiecki utrzymywał, że Polacy wzięli udział w interwencji na rzecz Bogdana bez zgody króla, który nie wiedział o zmianie na tronie hospodarskim z inspiracji Stambułu. Ponadto hetman domagał się przepuszczenia wojsk Mieleckiego przez granice, grożąc zaangażowaniem się oddziałów wojska koronnego po stronie wojewody podolskiego w razie konieczności. Argumentacja Jazłowieckiego przekonała sandżakbega białogrodzkiego do odstąpienia od Dniestru, przez który następnie przeprawił się Mielecki wraz z towarzyszami ${ }^{50}$. Taki obrót rzeczy stanowił faktyczne uznanie przez Rzeczpospolitą Iwonii jako hospodara mołdawskiego.

Równocześnie w Stambule Taranowski usiłował uzyskać od sułtana przebaczenie, oraz zwrot tronu. Cała sprawa układała się pomyślnie, dopóki Selim i jego najbliżsi doradcy nie zorientowali się, że równocześnie, gdy poseł prowadził negocjacje, wojska polskie pod wodzą wojewody podolskiego, realizowały w Mołdawii coś, co byśmy dzisiaj nazwali polityką faktów dokonanych. Mehmed Sokołłu dowiedziawszy się o obecności w Mołdawii wojsk polskich z Mikołajem Mieleckim na czele, wpadł w typowy dla swojej osoby szał. Podobnie, jak w przypadku Zborowskiego posypały się gniewne słowa. Przysłał Machmed basza po Taranowskiego, pytając, co to za ludzie $w$ Wotoszech $w$ ziemi pana mego? Tyś tu na zdradzie przyjechat, temu wierz, żeć to gardtem zaptacić. Jako skromnie Onego pohańca ułagodzit, nas wszystkie cośmy z nim byli, roztropnościq swa wyswobodzit, że jako w Polsce takiejeśmy wolności używali, $i$ wczas na wszem dostatek żywności sobie i koniom milei ${ }^{51}$. Poseł nie tylko zdołał wybrnąć z niezwykle niezręcznej i niebezpiecznej sytuacji, ale również doprowadził do ułaskawienia Bogdana, który miał otrzymać żelazny list, pojawić się w Stambule i ukorzyć przed sułtanem ${ }^{52}$. Dawało to jedynie cień nadziei na korzystny obrót sprawy na drodze mediacji oraz zapewne zobowiązania się przez byłego hospodara do płacenia większego haraczu ${ }^{53}$. Wobec przybycia czausza Ahmeda

50 M. Bielski, op. cit., t. II, s. 1218-1219; S. Lasicki, op. cit., s. 23-25.

51 B. Paprocki, op. cit., s. 428.

52 BCzart nr 80, s. 629-630: „List Sulejmana do Zygmunta Augusta pisany o wojewodzie wołoskim Bogdanie", Stambuł, b.d.; B. Paprocki, op. cit., s. 428, 826-827; List Selima II do Zygmunta Augusta, Stambuł, 15-24 IV 1572 r., List Mehmeda Sokotłu do Zygmunta Augusta, Stambuł, 15-24 IV 1572 r. [w:] KDT, nr 218, s. 210-211, nr 219, s. 211,

53 B. Paprocki, op. cit., s. 428, 826-827; KDT, nr 218, s. 210-211, List Selima II do Zygmunta Augusta, Stambuł, 15-24 IV 1572 r., nr 219, s. 211, List Mehmeda Sokołłu do Zygmunta Augusta, Stambuł, 15-24 IV 1572 r. 
z odpowiedzią sułtańską dopiero 3 czerwca, interwencji polskiej oraz stanowiska, na jakim w negocjacjach z sandżakbegiem Białogrodzkim stanął reprezentujący dyplomację koronną hetman Jazłowiecki, misja Taranowskiego nie miała większego znaczenia ${ }^{54}$. Tymczasem na granicy polsko-mołdawskiej poza wytargowaniem wolnego przejazdu dla oddziałów Mieleckiego hetman przyjął również od nowego hospodara hołd lenny, zatajając przed nim wiadomości o śmierci Zygmunta Augusta. Jazłowiecki wykazał się dość dużą przytomnością umysłu, mając na uwadze same okoliczności przyjęcia hołdu, który dawał na przyszłość dyplomacji Rzeczypospolitej punkty zaczepienia zarówno w negocjacjach z Wysoką Portą, jak i samym Iwonią. Kartą przetargową w negocjacjach prowadzonych przez hetmana stał się między innymi zamek chocimski nadal broniony przez, będącego uprzednio na służbie Bogdana IV, Dobrosławskiego. Sam były hospodar miał zostać dostarczony do Stambułu w towarzystwie posła koronnego. Do tego jednak nie doszło ze względu na śmierć króla i rychły wyjazd Bogdana IV do Wielkiego Księstwa Moskiewskiego. Ponadto Jazłowiecki z polecenia Zygmunta Augusta upominał się o zatrzymane podczas interwencji Mieleckiego wozy królewskie z towarami luksusowymi zakupionymi w Stambule ${ }^{55}$.

Analizując omówione wyżej wzajemne relacje polsko-mołdawskie wpisujące się w regnum ostatniego Jagiellona, można wyróżnić dwa okresy. Pierwszy obejmujący lata 1551-1563 charakteryzował się wzmożonymi akcjami poddanych Zygmunta Augusta działających na rzecz nastawionych antyturecko pretendentów do tronu, albo w interesie własnej osoby. Przedsięwzięcia te odbywały się nierzadko przy udziale strony habsburskiej, usiłującej doprowadzić do pogorszenia relacji polsko-tureckich. Król starał się takim akcjom przeciwdziałać, wykonując przy tym liczne pojednawcze gesty w stronę Stambułu. Paradoksem jest fakt, iż każdy z hospodarów wprowadzonych na tron przy udziale zarówno strony polsko-litewskiej, jak i habsburskiej ostatecznie zwracał się w stronę ciemiężyciela, za jakiego uznawano powszechnie Wysoką Portę. Charakterystyczny jest przypadek Aleksandra IV, który prowadził aktywną politykę zagraniczną, stanowiącą integralną część tureckiej dyplomacji.

Okres drugi obejmujący lata 1563-1572 jest zgoła odmienny. Król prowadzący dotąd w kwestii Mołdawii dość pasywną politykę, stara się uzyskać wpływ na wybór hospodara, czemu miała służyć droga dyplomatyczna. Ewidentnym błędem okazało się dokonanie interwencji w interesie nastawionego propolsko Bogdana. Przez całe swoje panowanie Zygmunt August raczej ufał swojej dyplomacji, co szło poniekąd w parze z dobrymi relacjami z Sulejmanem I. Tym

\footnotetext{
54 A. Dziubiński, Stosunki dyplomatyczne..., s. 269.

55 BRacz nr 196, s. 185-189, List Wojewody Wołoskiego do Panów Rad Koronnych, Chocim 28 VII 1572 r.; 219-220; 224-226; Odpowiedź wojewodzie wołoskiemu, Knyszyn, 31 VIII 1572 r.; M. Bielski, op. cit., t. II, s. 1219; S. Łasicki, op. cit., s. 25 Ł. Górnicki, op. cit., s. 169-170.
} 
razem król nie zaczekał nawet na powrót albo jakiekolwiek wieści od swego przedstawicielstwa dyplomatycznego. Interwencja na rzecz Bogdana zaczęła się około połowy marca 1572 roku, podczas gdy odpowiedzi tureckiej można było się spodziewać w początkach maja ${ }^{56}$. Być może decyzja o interwencji podyktowana była osobą Bogdana, rokującą nadzieje na dobre stosunki sąsiedzkie oparte na związkach rodzinnych hospodara $\mathrm{z}$ rodami koronnymi.

Warto również zwrócić uwagę, że awanturnicze wyprawy inspirowane przez Mikołaja Sieniawskiego czy też Olbrachta Łaskiego, zapoczątkowały zainteresowanie elit polskich oraz władców mołdawskich, możliwościami wzajemnego zbliżenia, co przełożyło się na przełomie XVI i XVII wieku na powstanie wspólnego polsko-tureckiego kondominium nad hospodarstwem. Owo zbliżenie miało postać układów opartych na wspólnocie interesów lub też mariaży, które w późniejszym okresie szczególnie stymulowały zaangażowanie możnowładztwa Rzeczypospolitej w Mołdawii.

Stosunki polsko-mołdawskie są niezwykle interesującym fragmentem naszej historii i zasługują na dalsze badania. Dla dalszego pogłębienia tego zagadnienia niezbędne jest sięgnięcie do źródeł, jakie pozostawiły po sobie zarówno dyplomacja osmańska, jak i habsburska. Ponadto warto również, stworzyć nowe opracowanie, które obejmowałoby całość historii dyplomacji, jaką w XVI wieku na kierunku południowym prowadziło zarówno państwo polsko-litewskie, jak i reprezentujący nie do końca jego interesy możnowładcy.

\section{Poland and Moldavia in 1551-1572}

The aim of this article is to present Polish-Moldavian relations in the years 1551-1572. This period, which almost fully overlapped with the reign of Sigismund II Augustus, was characterized by a considerable dynamism of relations between Poland and Moldavia. It also constituted a prelude to increased activities of Polish-Lithuanian magnates of this region - especially at the end of the XVI century and in the two first decades of the XVII century. An interest in the region was caused by cultural and historical relations (going back to the medieval period) as well as ambitions and the reasons of State perceived through the prism of personal interests. Analyzing some chosen issues, one may indicate two periods in the bilateral relations of Poland and Moldavia. The years 1551-1563 are characterized by frequent actions of Polish-Lithuanian magnates on behalf

\footnotetext{
56 Podróż do Stambułu poselstwa albo kupca ze świtą, trwała wówczas przeciętnie około 37-45 dni, więc na efekty misji należało czekać minimum 2,5 miesiąca. Odpowiedzi na piśmie dla Taranowskiego została wystawiona w połowie kwietnia, więc musiał on wyruszyć najprawdopodobniej pod koniec lutego albo na początku marca. Alternatywą był transport lądowo-morski, co dawało około 25 dni podróży; A. Dziubiński, Na szlakach..., s. 26-27, 30.
} 
of anti-Turkish pretenders to the throne or on the magnates' own behalf, without Sigismund II Augustus's consent. Those efforts were also supported by the Habsburgs, who aimed at the deterioration of Polish-Turkish relations. Sigismund II Augustus made attempts to oppose these actions, making conciliatory gestures towards Istanbul. It is worth mentioning that each hospodar on the Moldavian throne in that period was bound to turn to Turkey to save his rule. The second period, comprising the years 1563-1572, is different, due to the attitude of Zygmunt August, who rejected passive policy and tried, mainly through diplomatic efforts, to gain influence on the choice of a hospodar. Periods of the rule of Aleksander Lapusneau and his son - Bogdan, resulted from Sigismund II Augustus's effective efforts. In 1572, on the king's inspiration, a subsequent Polish intervention took place to support the abolished hospodar - Bogdan. Military and diplomatic activities were undertaken simultaneously. Because of the strong Turkish-Tatar support, the undertaking turned out to be a failure. The situation was additionally complicated by the death of Sigismund II Augustus. 